\title{
Phase Relations in the Ti-Si-C System
}

\author{
W. J. J. Wakelkamp, F. J. J. van Loo \& R. Metselaar* \\ Eindhoven University of Technology, Laboratory for Solid State Chemistry and Materials Science, \\ P.O. Box 513, 5600 MB Eindhoven, The Netherlands
}

(Received 2 February 1991; revised version received 27 March 1991; accepted 11 April 1991)

\begin{abstract}
For the system $\mathrm{Ti}-\mathrm{Si}$-C phase diagrams at $1373 \mathrm{~K}$ and at $1523 \mathrm{~K}$ were determined. For that purpose, several alloys and diffusion couples were equilibrated and analysed by EPMA (electron probe microanalysis) polarised light microscopy and $X$-ray diffraction. With EPMA the composition of the alloys could be determined accurately by measuring the titanium, silicon and carbon contents. Some differences were found with the known diagram from the literature.
\end{abstract}

Für das System Ti-Si-C wurden die Phasendiagramme bei $1373 \mathrm{~K}$ und bei $1523 \mathrm{~K}$ bestimmt. Dazu wurden mehrere Legierungen und Diffusionspaare bei den angegebenen Temperaturen ins Gleichgewicht gebracht und mit EPMA, polarisiertem Licht und Röntgenbeugung analysiert. Mit Hilfe der EPMA konnte die genaue Zusammensetzung der Legierungen durch die Analyse von Titan, Silizium und Kohlenstoff festgestellt werden. Es wurden einige Abweichungen von dem bekannten Diagramm aus der Literatur gefunden.

On a déterminé les diagrammes de phases à 1373 et $1523 \mathrm{~K}$ du système $T i-S i-C$. A cette fin, on a porté à l'équilibre plusieurs alliages et couples de diffusion et on les a analysés par EPMA, microscopie à lumière polarisée et diffraction X. L'analyse EPMA nous a permis de déterminer avec précision la compositions des alliages par analyse des teneurs en titane, silicium et carbone. On a relevé certaines différences avec les diagrammes disponibles dans la littérature.

\section{Introduction}

Nowadays combinations of metals and ceramics are receiving full attention as new materials. Applic-

* To whom all correspondence should be addressed. ations of these new materials in e.g. cutting tools, aerospace engines, or as composite materials in the aircraft industry are very promising. In all these applications the interaction between the metal and ceramic is of crucial importance. In this laboratory the authors are studying this interaction specifically for combinations of titanium (with and without aluminium) with silicon carbide and with silicon nitride. This interaction is being investigated with the so-called diffusion-couple technique and an attempt to predict the reaction layer sequence, morphology and reaction rate according to the model developed by van Loo et al. ${ }^{1}$ is being made. To use this model the phase diagrams of the systems $\mathrm{Ti}-\mathrm{Si}-\mathrm{C}$ and $\mathrm{Ti}-\mathrm{Si}-\mathrm{N}$ are needed, which are not reliably known up to now. In this article attention is focused upon the $\mathrm{Ti}-\mathrm{Si}-\mathrm{C}$ system. Firstly the data given in the literature will be discussed. In the second part the experiments performed to determine the isothermal cross-sections of the phase diagram will be reported, followed by a discussion of the results. Finally some conclusions are drawn.

\subsection{Literature data on the Ti-Si-C system}

The only experimentally determined diagram of this system in the literature to the authors' knowledge is the one determined by Bruck ${ }^{2}$ at $1473 \mathrm{~K}$ (Fig. 1). The principal features of this diagram are the ternary phase $\mathrm{T} 1$ with the general formula $\mathrm{Ti}_{3} \mathrm{SiC}_{2}$ and the solid solution of carbon in $\mathrm{Ti}_{5} \mathrm{Si}_{3}$ (T2). Jeitschko \& Nowotny ${ }^{3}$ determined the crystal structure of $\mathrm{Ti}_{3} \mathrm{SiC}_{2}$ to be hexagonal with lattice parameters $a=3.06 \AA$ and $c=17.66 \AA$. The structure type belongs to the class of complex carbides having octahedral groups $\left(\mathrm{T}_{6} \mathrm{C}\right)$. Carbon can be dissolved up to about 10 at. $\%$ in $\mathrm{Ti}_{5} \mathrm{Si}_{3}$. However, the diagram published by Bruckl leaves some questions.

Firstly, the binary Ti-Si phase diagram shows a

Journal of the European Ceramic Society 0955-2219/91/\$3.50 (C) 1991 Elsevier Science Publishers Ltd, England. Printed in Great Britain 


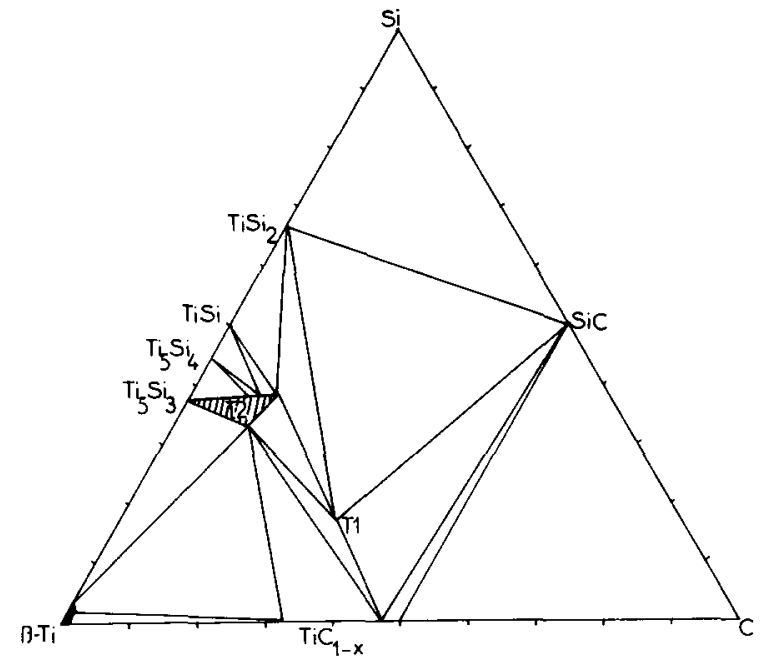

Fig. 1. The phase diagram of Ti-Si-C at $1473 \mathrm{~K}$ from Bruckl. ${ }^{2}$

homogeneity region for $\mathrm{Ti}_{5} \mathrm{Si}_{3},{ }^{4}$ from 61 at. $\%$ up to 63.8 at. $\% \mathrm{Ti}$, whereas it is reported by Bruckl as a line compound without any homogeneity region. The extension of this region on addition of carbon seems unrealistic in comparison with e.g. $\mathrm{Mo}_{5} \mathrm{Si}_{3} .{ }^{5}$ Furthermore, the phase field $\mathrm{T} 2-\mathrm{Ti}_{5} \mathrm{Si}_{4}$ is contradicting thermodynamic rules. Finally, it is not very likely that $\mathrm{TiC}_{1-y}$ is in equilibrium with only one composition of the T2 phase. No diagram was available at temperatures $<1473 \mathrm{~K}$, where the $\mathrm{Ti}_{3} \mathrm{Si}$ phase is stable. ${ }^{2}$ Therefore it was decided to reinvestigate this diagram at $1373 \mathrm{~K}$ and $1523 \mathrm{~K}$.

\section{Experimental Procedure}

The starting materials were titanium powder (99.5\%, Goodfellow, UK); titanium $\operatorname{rod}(99.7 \%$, Alpha Europe Products, Karlsruhe, FRG); silicon powder (technical purity, No. 13733, Reidel-De Haen AG, Hannover, Germany); silicon rod (single crystal, Philips, Eindhoven, The Netherlands); carbon powder (purriss., Roth, Karlsruhe, FRG); silicon carbide (hot-pressed, without sintering additives, ESK, Munich, FRG). The alloys were made by arc-melting pre-pressed mixtures of titanium, silicon and carbon, or titanium and silicon of about $3 \mathrm{~g}$ total weight. This was done by using $\mathrm{Ti}$ and Si powder as well as rods. After melting the alloys were equilibrated at the desired temperature in an alumina tube-furnace for about two weeks. The alloys were sealed in a molybdenum capsule, which was carried out by welding a Mo lid on a Mo cylinder under 0.66 bar Argon, in a vacuum chamber which had been evacuated to $10^{-9}$ bar. In the tube-furnace a $\mathrm{H}_{2} / \mathrm{N}_{2}$ mixture (20/80 by volume) prevented the molybdenum capsule from oxidation. The titanium-silicon-carbon alloys were then sawn, ground and polished up to $1 \mu \mathrm{m}$ diamond. Examination was done by optical microscopy using polarised light, electron probe microanalysis (EPMA) and X-ray diffraction.

The carbon analysis was performed by measuring the $K_{\alpha}$ intensity at $10 \mathrm{keV}$ and $300 \mathrm{nA}$ with $\mathrm{Fe}_{3} \mathrm{C}$ as a carbon standard using the PROZA correction program of Bastin \& Heijligers. ${ }^{6,7}$ To prevent the build up of a carbonaceous layer at the point of impact of the electron beam (system contaminations) an air-jet was used. For measuring Ti and $\mathrm{Si}$, pure $\mathrm{Ti}$ and $\mathrm{Si}$ were used as standards. For the investigation of the equilibria in the $\mathrm{Ti}-\mathrm{Si}-\mathrm{C}$ system, several diffusion couples of the type $\mathrm{Ti}_{x} \mathrm{Si}_{1-x} / \mathrm{SiC}$ were also annealed at $1373 \mathrm{~K}$ and $1523 \mathrm{~K}$ in a vacuum furnace $\left(<10^{-9}\right.$ bar, tungsten heating elements, shielded from the diffusion

Table 1. Alloys used to determine the phase diagrams of the Ti-Si-C system at $1373 \mathrm{~K}$ and $1523 \mathrm{~K}$

\begin{tabular}{|c|c|c|}
\hline Composition of alloy & Temperature $(K)$ & Equilibrium phases \\
\hline $\mathrm{Ti}_{0 \cdot 74} \mathrm{Si}_{0 \cdot 26}$ (powder) & 1373 & $\beta-\mathrm{Ti}, \mathrm{Ti}_{5} \mathrm{Si}_{3}$ \\
\hline $\mathrm{Ti}_{0.74} \mathrm{Si}_{0.26}(\mathrm{rod})$ & 1373 & $\mathrm{Ti}_{3} \mathrm{Si}$ \\
\hline $\mathrm{Ti}_{0.67} \mathrm{Si}_{0 \cdot 13} \mathrm{C}_{0 \cdot 20}$ & 1373 & $\beta$-Ti, $\mathrm{Ti}_{0.62} \mathrm{Si}_{0.35} \mathrm{C}_{0.03}, \mathrm{TiC}_{1-y}$ \\
\hline $\mathrm{Ti}_{0.44} \mathrm{Si}_{0.53} \mathrm{C}_{0.03}$ & 1373 & $\mathrm{Ti}_{0.56} \mathrm{Si}_{0.35} \mathrm{C}_{0.09}, \mathrm{TiSi}_{2}, \mathrm{TiSi}$ \\
\hline $\mathrm{Ti}_{0.45} \mathrm{Si}_{0.39} \mathrm{C}_{0.16}$ & 1373 & $\mathrm{Ti}_{0.55} \mathrm{Si}_{0.34} \mathrm{C}_{0.11}, \mathrm{TiSi}_{2}, \mathrm{Ti}_{0.50} \mathrm{Si}_{0.17} \mathrm{C}_{0.33}$ \\
\hline $\mathrm{Ti}_{0.67} \mathrm{Si}_{0.29} \mathrm{C}_{0.04}$ & 1373 & $\mathrm{Ti}_{0.63} \mathrm{Si}_{0.35} \mathrm{C}_{0.02}, \beta-\mathrm{Ti}$ \\
\hline $\mathrm{Ti}_{0.37} \mathrm{Si}_{0.20} \mathrm{C}_{0.43}$ & 1373 & $\mathrm{TiC}, \mathrm{SiC}, \mathrm{Ti}_{0.50} \mathrm{Si}_{0.15} \mathrm{C}_{0.35}$ \\
\hline $\mathrm{Ti}_{0.53} \mathrm{Si}_{0.14} \mathrm{C}_{0.33}$ & 1373 & $\mathrm{Ti}_{5} \mathrm{Si}_{3} \mathrm{C}_{x}, \mathrm{TiC}_{1-y}$ \\
\hline $\mathrm{Ti}_{0.28} \mathrm{Si}_{0.45} \mathrm{C}_{0.27}$ & 1373 & $\mathrm{Ti}_{0.49} \mathrm{Si}_{0.17} \mathrm{C}_{0.34}, \mathrm{SiC}, \mathrm{TiSi}_{2}$ \\
\hline $\mathrm{Ti}_{0.52} \mathrm{Si}_{0.17} \mathrm{C}_{0.31}$ & 1373 & $\mathrm{Ti}_{0.57} \mathrm{Si}_{0.32} \mathrm{C}_{0.11}, \mathrm{Ti}_{0.51} \mathrm{Si}_{0.16} \mathrm{C}_{0.33}, \mathrm{TiC}_{1-y}$ \\
\hline $\mathrm{Ti}_{0.84} \mathrm{Si}_{0.07} \mathrm{C}_{0.09}$ & 1373 & $\mathrm{Ti}_{0.62} \mathrm{Si}_{0.35} \mathrm{C}_{0.03}, \beta-\mathrm{Ti}, \mathrm{TiC}_{1-y}$ \\
\hline $\mathrm{Ti}_{0.52} \mathrm{Si}_{0.45} \mathrm{C}_{0.03}$ & 1373 & $\mathrm{Ti}_{5} \mathrm{Si}_{3} \mathrm{C}_{\boldsymbol{x}}, \mathrm{Ti}_{5} \mathrm{Si}_{4}, \mathrm{TiSi}$ \\
\hline $\mathrm{Ti}_{0.57} \mathrm{Si}_{0 \cdot 40} \mathrm{C}_{0.03}$ & 1373 & $\mathrm{Ti}_{5} \mathrm{Si}_{3} \mathrm{C}_{x}, \mathrm{Ti}_{5} \mathrm{Si}_{4}$ \\
\hline $\mathrm{Ti}_{0.74} \mathrm{Si}_{0.26}$ & 1523 & $\beta$-Ti, $\mathrm{Ti}_{5} \mathrm{Si}_{3}$ \\
\hline $\mathrm{Ti}_{0.66} \mathrm{Si}_{0.14} \mathrm{C}_{0.20}$ & 1523 & $\beta-\mathrm{Ti}, \mathrm{TiC}_{1-y}, \mathrm{Ti}_{0.63} \mathrm{Si}_{0.34} \mathrm{C}_{0.03}$ \\
\hline $\mathrm{Ti}_{0.44} \mathrm{Si}_{0.53} \mathrm{C}_{0.04}$ & 1523 & $\mathrm{Ti}_{0.54} \mathrm{Si}_{0.35} \mathrm{C}_{0 \cdot 10}, \mathrm{TiSi}_{2}, \mathrm{TiSi}$ \\
\hline $\mathrm{Ti}_{0 \cdot 46} \mathrm{Si}_{0 \cdot 39} \mathrm{C}_{0 \cdot 15}$ & 1523 & $\mathrm{Ti}_{0.53} \mathrm{Si}_{0.36} \mathrm{C}_{0.11}, \mathrm{Ti}_{0.49} \mathrm{Si}_{0 .}{ }_{16} \mathrm{C}_{0.36}, \mathrm{TiSi}_{2}$ \\
\hline $\mathrm{Ti}_{0.67} \mathrm{Si}_{0.28} \mathrm{C}_{0.05}$ & 1523 & $\beta-\mathrm{Ti}, \mathrm{Ti}_{0.63} \mathrm{Si}_{0.34} \mathrm{C}_{0.03}, \mathrm{TiC}_{1-y}$ \\
\hline $\mathrm{Ti}_{0.52} \mathrm{Si}_{0.17} \mathrm{C}_{0.31}$ & 1523 & $\mathrm{Ti}_{0.55} \mathrm{Si}_{0 \cdot 34} \mathrm{C}_{0 \cdot 11}, \mathrm{Ti}_{0 \cdot 49} \mathrm{Si}_{0 \cdot 16} \mathrm{C}_{0 \cdot 35}, \mathrm{TiC}_{1-y}$ \\
\hline
\end{tabular}


Table 2. Various diffusion couples annealed during $100 \mathrm{~h}$ at the given temperatures

\begin{tabular}{lcl}
\hline Couple type & Temperature $(K)$ & \multicolumn{1}{c}{ Phases in equilibrium } \\
\hline $\mathrm{Ti}(\mathrm{foil})-\mathrm{SiC}$ & 1499 & $\left(\mathrm{TiSi}_{2}+\mathrm{Ti}_{3} \mathrm{SiC}_{2}\right) / \mathrm{SiC}$ \\
$\mathrm{TiSi}-\mathrm{SiC}$ & 1523,1373 & $\mathrm{TiSi}_{2} \mathrm{Ti}_{5} \mathrm{Si}_{3} \mathrm{C}_{x} / \mathrm{TiSi}_{2} / \mathrm{Ti}_{3} \mathrm{SiC}_{2} / \mathrm{SiC}$ \\
$\mathrm{Ti}_{5} \mathrm{Si}{ }_{3}-\mathrm{SiC}$ & 1523,1373 & $\mathrm{Ti}_{5} \mathrm{Si}_{3} \mathrm{C}_{x} / \mathrm{TiSi}_{2} / \mathrm{Ti}_{3} \mathrm{SiC}_{2} / \mathrm{SiC}$ \\
$\mathrm{Ti}-\mathrm{SiC}$ & 1523,1373 & $\mathrm{Ti}\left(\mathrm{C}, \mathrm{Si}^{2}\right) / \mathrm{Ti}_{5} \mathrm{Si}_{3} \mathrm{C}_{x} / \mathrm{Ti}_{5} \mathrm{Si}_{3} \mathrm{C}_{x}+\mathrm{TiC}_{1-y} / \mathrm{Ti}_{3} \mathrm{SiC}_{2} / \mathrm{SiC}$
\end{tabular}

$=$ Interface with phases on both sides in equilibrium.

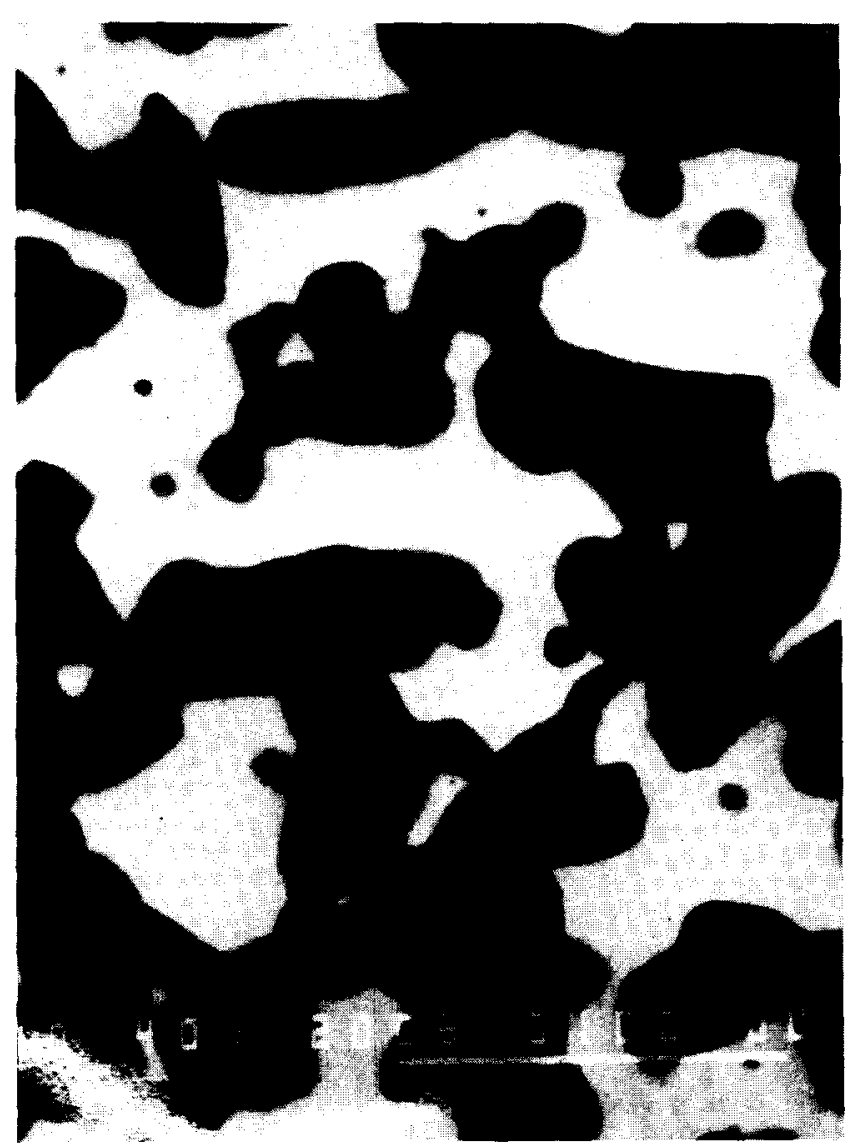

Fig. 2. A SEM micrograph of a Ti-Si-C alloy equilibrated at $1523 \mathrm{~K}$ with white phase $=\beta-\mathrm{Ti}$, grey phase $=\mathrm{Ti}_{5} \mathrm{Si}_{3} \mathrm{C}_{x}$ and black phase $=\mathrm{TiC}_{1-y}$.

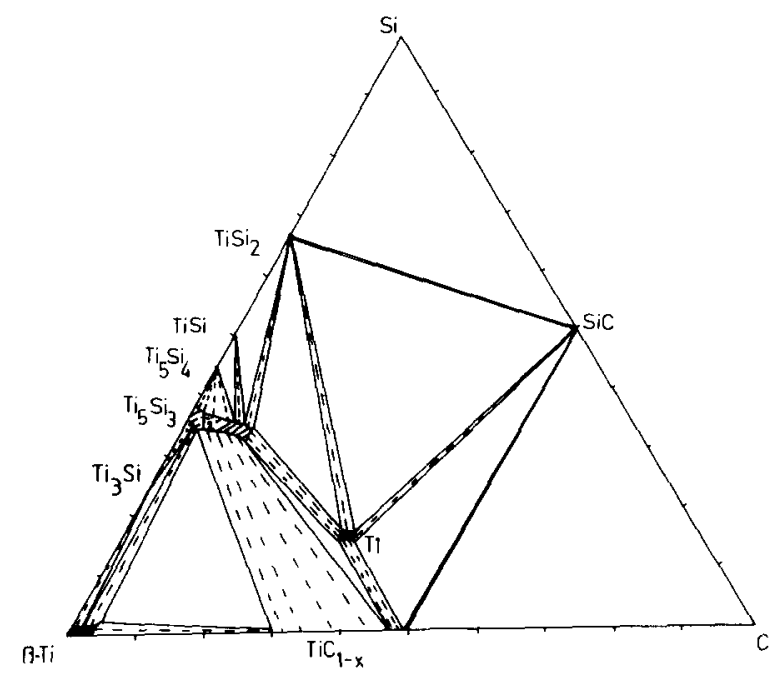

Fig. 3. The phase diagram of $\mathrm{Ti}-\mathrm{Si}-\mathrm{C}$ at $1373 \mathrm{~K}$ determined in this work. $\mathrm{T} 1=\mathrm{Ti}_{3} \mathrm{SiC}_{2}$ and $\mathrm{T} 2=\mathrm{Ti}_{5} \mathrm{Si}_{3} \mathrm{C}_{x}$. couple). Before annealing the couple halves were ground and polished up to $3 \mu \mathrm{m}$ diamond and ultrasonically cleaned in acetone. After annealing for $100 \mathrm{~h}$, the couples were sawn with a low-speed diamond saw perpendicular to the interface between the couple halves. Next, these cross-sections were ground and polished up to $1 \mu \mathrm{m}$, again using diamond paste, and after polishing were ultrasonically cleaned in acetone. The reaction products formed between the two original couple halves are analysed by optical microscopy and EPMA. The equilibria at the phase interfaces should be the same as those given in the phase diagram. ${ }^{8}$

\section{Results and Evaluation}

Table 1 shows the composition of the alloys that were used to determine the phase diagram. The three analysing methods which were used gave consistent results. With microprobe analyses the composition of the different phases in the $\mathrm{Ti}-\mathrm{Si}-\mathrm{C}$ alloy in equilibrium was accurately determined. Figure 2 shows an example of an alloy with the phases $\beta$-Ti, $\mathrm{Ti}_{5} \mathrm{Si}_{3} \mathrm{C}_{x}$ and $\mathrm{TiC}_{1-y}$ as identified by EPMA. Table 2 gives the different diffusion couples that were annealed, giving the reaction products in equilibrium with each other.

\subsection{Ti-Si-C alloys}

Figures 3 and 4 show the phase diagrams determined at $1373 \mathrm{~K}$ and $1523 \mathrm{~K}$. The ternary compound $\mathrm{T} 1$ has at $1373 \mathrm{~K}$ a clear homogeneity region, contrary to the line compound suggested by Bruckl ${ }^{2}$ at $1473 \mathrm{~K}$. At $1523 \mathrm{~K}$ a narrower homogeneity range is found. Also, the homogeneity range of the $\mathrm{T} 2$ phase and its compositions which are in equilibrium with $\mathrm{TiC}_{1-y}$ are different from Bruckl's diagram. The $\mathrm{Ti}_{3} \mathrm{Si}$ phase is present at $1373 \mathrm{~K}$ and decomposes into $\mathrm{T} 2$ and $\beta$ - $\mathrm{Ti}$ when only very little carbon is added to the system. A similar behaviour can be seen in the case where a small amount of oxygen is present as a third compound. This probably explains why many authors do not find this phase in their experiments. In line with other authors ${ }^{9}$ it is believed 


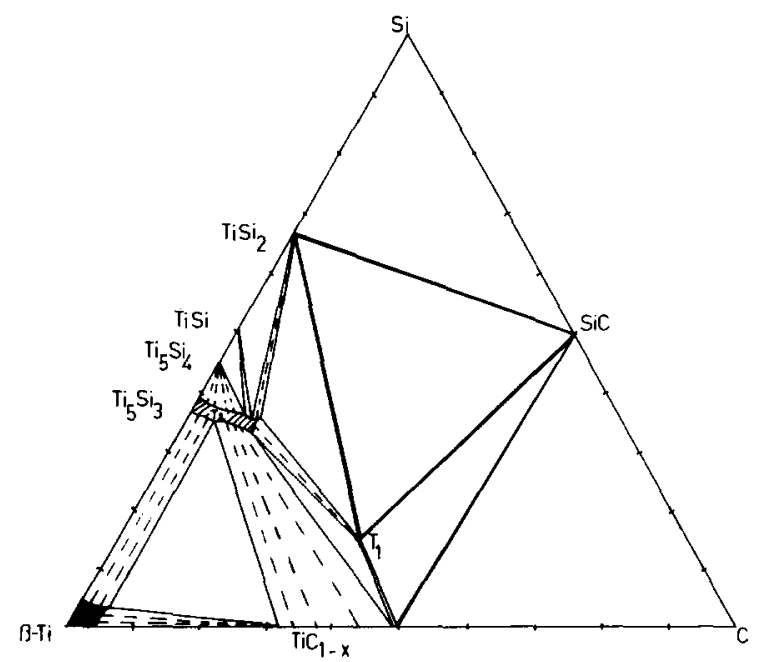

Fig. 4. The phase diagram of $\mathrm{Ti}-\mathrm{Si}-\mathrm{C}$ at $1523 \mathrm{~K}$ determined in this work. $\mathrm{T} 1=\mathrm{Ti}_{3} \mathrm{SiC}_{2}$ and $\mathrm{T} 2=\mathrm{Ti}_{5} \mathrm{Si}_{3} \mathrm{C}_{x}$.

that $\mathrm{Ti}_{3} \mathrm{Si}$ is destabilised by oxygen. Therefore experiments were performed to make $\mathrm{Ti}_{3} \mathrm{Si}$ from titanium rod and silicon single crystal and also from the respective powders. In the latter case the presence of adsorbed oxygen could surely be expected. Indeed $\mathrm{Ti}_{3} \mathrm{Si}$ was found in the first case and not in the alloy made from powders. In the latter case about 1 at. $\%$ oxygen was measured in $\mathrm{Ti}_{5} \mathrm{Si}_{3}$. The present diagram fits well with the diagram calculated by Touanen et al. ${ }^{10}$ for $1500 \mathrm{~K}$.

\subsection{Diffusion couples}

When two different materials are put together at high temperature diffusion will take place. After a sufficiently long time there will be equilibrium at the interfaces of the reaction products. In Fig. 5 a micrograph is shown of a reaction layer in a diffusion couple, taken by means of a scanning electron microscope. In this micrograph the phases that are in thermodynamic equilibrium with each

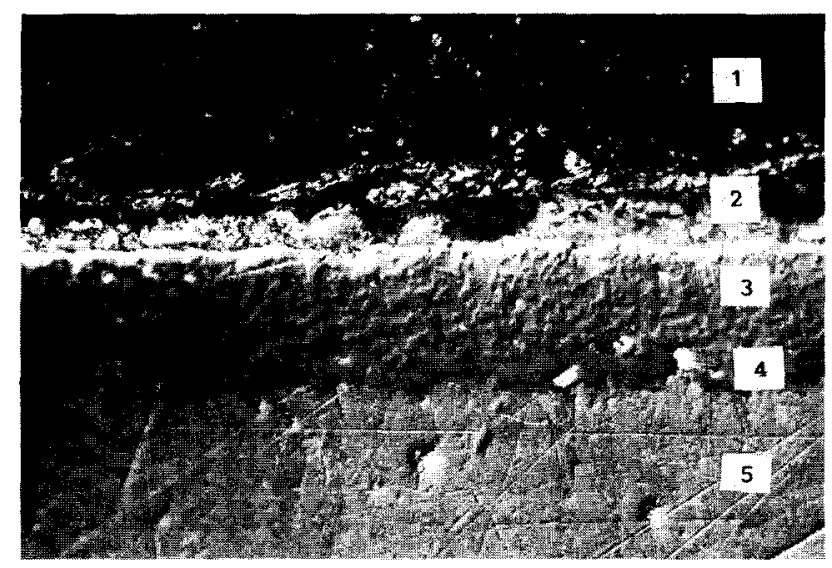

Fig. 5. Optical micrograph of a diffusion reaction layer between titanium and silicon carbide annealed for $100 \mathrm{~h}$ at $1373 \mathrm{~K}$. The total layer thickness is $45 \mu \mathrm{m}$. $1=\mathrm{HipSiC}, 2=\mathrm{Ti}_{3} \mathrm{SiC}_{2}, 3=$ $\mathrm{Ti}_{5} \mathrm{Si}_{3} \mathrm{C}_{x}+\mathrm{TiC}_{1-y}, 4=\mathrm{Ti}_{5} \mathrm{Si}_{3} \mathrm{C}_{x}, 5=\beta-\mathrm{Ti}$. other at the interfaces can be seen. The phases are identified with help of EPMA and shown in Table 2.

In the semi-infinite couple between thick pieces of $\mathrm{Ti}$ and $\mathrm{SiC}$ equilibria between $\mathrm{Ti}_{5} \mathrm{Si}_{3} \mathrm{C}_{x}$ and $\mathrm{TiC}_{1-y}$, between $\mathrm{Ti}_{3} \mathrm{SiC}_{2}$ and $\mathrm{Ti}_{5} \mathrm{Si}_{3} \mathrm{C}_{x}$, and between $\mathrm{Ti}_{5} \mathrm{Si}_{3} \mathrm{C}_{x}$ and the solid solution of carbon and silicon in titanium are found. In the case of the titanium foil between two pieces of silicon carbide, the metal has reacted completely. No initial titanium was left. As is expected from the phase diagram, the reaction products are $\mathrm{TiSi}_{2}$ and $\mathrm{Ti}_{3} \mathrm{SiC}_{2}$, which are situated as a mixture between the two pieces of SiC. Finally, from the $\mathrm{TiSi} / \mathrm{SiC}$ couples an equilibrium between $\mathrm{Ti}_{5} \mathrm{Si}_{3} \mathrm{C}_{x}$ and $\mathrm{TiSi}_{2}$ and between $\mathrm{Ti}_{3} \mathrm{SiC}_{2}$ and $\mathrm{TiSi}_{2}$ was found.

\section{Conclusion}

The phase diagrams of $\mathrm{Ti}-\mathrm{Si}-\mathrm{C}$ are now accurately determined at $1373 \mathrm{~K}$ and $1523 \mathrm{~K}$ and show some differences with the diagram known up to now. At $1373 \mathrm{~K}$ the ternary $\mathrm{T} 1$ phase has a homogeneity range (about 1 at. \% in C, 0.7 at. \% in Si and 1.2 at. \% in $\mathrm{Ti}$ ) and seems to become a line compound at $1523 \mathrm{~K}$. Also the shape of the homogeneity range of the $\mathrm{T} 2$ phase is different. It is clear that this phase is a solid solution of carbon in $\mathrm{Ti}_{5} \mathrm{Si}_{3}$ without a change in the $\mathrm{Ti} / \mathrm{Si}$ ratio. The stability of the $\mathrm{Ti}_{3} \mathrm{Si}$ phase is obviously strongly influenced by the presence of impurities like carbon and oxygen. With the help of diffusion couples it is possible to determine a great part of the equilibria between the phases in an isothermal cross-section of the phase diagram.

\section{Acknowledgement}

The investigations were supported by the Netherlands Foundation for Chemical Research (SON) with financial aid from the Netherlands Organisation for Scientific Research (NWO).

\section{References}

1. Van Loo, F. J. J., van Beek, J. A., Bastin, G. F. \& Metselaar, R., The role of thermodynamics and kinetics in multiphase ternary diffusion. In Diffusion in Solids, ed. M. A. Dayanada \& G. E. Murch. The Metallurgical Society, Warrendale, 1985 , pp. 231-9.

2. Bruckl, C. E., Ternary phase equilibria in transition-boroncarbon-silicon systems, Part II, Vol. VII, AFML-TR-65-2. Metals and Ceramics Division, Air Force Laboratory, Wright-Patterson Air Force Base, OH, 1966.

3. Jeitschko, W. \& Nowotny, H., Die Kristallstruktur von $\mathrm{Ti}_{3} \mathrm{SiC}_{2}$-ein neuer Komplexcarbid-Typ. Mh. für Chem., 98 (1967) 329-37.

4. Massalski, T. B., Binary alloy phase diagrams, Vol. 2. 
American Society for Metals, Metals Park, OH, 1986. pp. 2054-6

5. Van Loo, F. J. J., Smet, M., Rieck, G. D. \& Verspui, G., Phase relations and diffusion paths in the $\mathrm{Mo}-\mathrm{Si}-\mathrm{C}$ system at $1200^{\circ}$ C. High Temp. High Press., 14 (1982) 25-31.

6. Bastin, G. F. \& Heijligers, H. J. M., Quantitative electron probe microanalysis of carbon in binary carbides. I. Principles and procedures, $X$-Ray Spectroscopy, 15 (1986) $(135-41)$.

7. Bastin, G. F. \& Heijligers, H. J. M., Quantitative electron probe microanalysis of carbon in binary carbides. II. Data reduction and comparison of programs. X-Ray Specroscopl', 15 (1986) 143-50.
8. Van Loo, F. J. J., Multiphase diffusion in binary and ternary solid-state systems. Progr. Solid State Chem., 20 (1990) 47-99.

9. Pieraggi, B., Raffy, M.\& Dabosi, F., Oxidation of $\mathrm{Ti}_{-} \mathrm{Ti}_{5} \mathrm{Si}_{3}$ eutectic alloy. In Intern. Congr. on Metallic Corrosion, Toronto, Volume 3, June 1984

10. Touanen, M., Teyssandier, F. \& Ducarroir, M., Thermodynamic calculation of the two-phased deposition domains with $\mathrm{SiC}$ in the $\mathrm{Si}-\mathrm{Ti}-\mathrm{C}-\mathrm{Cl}-\mathrm{H}$ chemical system. In Proc. of the Seventh Eur. Conf. on Chemical Vapour Deposition, Perpignan, France, June 1989, ed. M. Ducarroir, C. Bernard \& L. Vandenbulcke. Journal de Physique, 50 (1989) C5$105-113$. 